Klassikern:

\title{
ETT MUSEIMANIFEST ÅR 1862
}

\section{Carl Robert Ehrström}

Museer eller efter en viss plan uppställda samlingar af sådana föremål, som ej mindre eget land än främmande länder hafva att erbjuda - märkvärdiga, nyttiga, nöjsamma, lärorika - hafva redan i de flesta civiliserade länder blifvit erkända såsom en vigtig häfstång för bildningens spridande bland både hög och låg, ja hos många redan blifvit ett oafvisligt behof.

Det är i sådana samlingar folken bevarat minnen från förgångna tider och de utgöra då, likasom traditionerna i folkets mun, visserligen lösbrutna, men dock alltid värderika stycken, dem häfdeforskaren sedan sammanlänkar, och hvarur han stundom lyckas draga de mest oväntade resultater. De äro, så att säga, en plastisk historia i fragmenter, en historiens höjdkarta. Hvarje den ringaste fornlemning kan blifva en vigtig ledtråd för någon timadt händelse. Det är derföre vår pligt att samla och förvara dem. Den enskilte har, efter en bortgången vän ett arf; det är en liten obetydlig sak, ett lappri, men det är ett dyrbart minne, det påminner om en vigtig händelse i lifvet; han vill icke för något förlora det. Så äro ock de historiska våra dyrbara minnen från forntiden; låtom oss förvara dem, men förvara dem så att de blifva allas egendom såsom de ock tillhöra alla.

Ära åt dem som offrar sitt enskilda för det allmänt nyttiga!

Ett annat ändamål hafva samlingar af natur och konstalster från främmande länder. Hvad de förenämnde äro för landet enskilt och dess historia, detsamma äro desse i ännu vida större skala. De representera hela verlden, hela skapelsen. De äro en åskådlig naturalhistoria. De bära vittne om Skaparens allmagt, skapelsens vishet och mångfald. De lära oss skatta, men icke öfverskatta hvad vi äga. De underrätta oss om mycket som oss ännu flear och visa oss vägen huru dessa brister skola fyllas.

Ännu en nytta af dylika samlingar vill jag påpeka. Då sjömannen efter att hafva plöjt hafvet och undgått dess faror kommer till en hamn, ett land vida rikligare, lyckligare begåfvadt af naturen än hans eget, då han ser dess öfverflöd, den lätthet hvarmed man der nästan utan arbete kan lefva, hvad är det då som ändå kallar honom tillbaka till sitt kalla, jemförelsevis ofruktbara hemland? "Pligten», säga vi 
kallt: han har svurit att återvända med samma fartyg på hvilket han seglat ut. «Fosterlandskärleken», säger en annan: han har sina barndomsminnen, han har slägt och vänner, förbindelser till hemmet af flere slag. Låtom oss icke heller glömma den vigtiga naturdriften, som nära omedveten, oförklarad, men mägtig, ofta oemotståndlig återkallar honom till det land der hans vagga stått, der hans förfäder hvila. Alla dessa band äro starka, men de kunna ännu ytterligare förstärkas. Sjömannen måste icke endast veta, att han har ett fädernesland, ett hem; han måste äfven å ena sidan minnas, att detta land sörjt för hans bildning, att han der haft trefnad, à andra sidan kunna hoppas att han i detta sitt hemland skall finna sin framtida bergning, der skall finna sin ålderdoms trefnad. Antagom nu att en från sina vida resor hemkommen sjöman är familjefar; antagom vidare att han under sina resor i främmande land, från den och den hamnen, från det hafvet, från den kusten, från det och det äfventyret medfört ett minne: antagom att han $\mathrm{i}$ en ledig stund med sin hustru, sina barn vid handen går att bese vårt museum och finner sina minnen uppställda: - säg skall han ej finna trefnad deraf, skall han ej för sina åhörare hafva att berätta hela historier (historier som nu vanligen förklinga $\mathrm{i}$ en obekant sfer eller ock alldrig se dagen) om dessa minnen och dermed förknippade händelser, skall icke hans hustru älska honom innerligare, då hon erfar huru lätt han kunnat vara för henne förloradt; skola icke de unga åhörarene gripas af lust att träda i fadrens fotspår (för dem äro äfventyr endast lockelser, pappa har ju kommit hem, hvarföre skulle icke äfven jag lyckas det); skola de icke önska att komma till länder som äro så herrliga, der sådana granna, underliga saker finnas. Vänta, en vacker dag skola ock saker, som jag hemtat, pryda denna samling, ock äfven mitt namn prunka bland etiketterna! - Se der en annan nytta som samlingarna skola medföra. De skola, äfven de, fästa sjömannen närmare vid, de skola återkalla honom till hemorten - de skola äfven de blifva ett af hans trefliga minnen.

Det är den vidsträckta, alla jordens länder förbindande sjöfartens förtjenst att hafva möjliggjort bildandet af de sistnämnde naturalhistoriska samlingarna, så äfven af museer i stort, sådana de finnas t.ex. i London, Paris m.fl. städer och orter, namnkunniga, verldsomfattande; och det är anläggandet af ett sådant jag äfven ville härmed förorda i Brahestad. Icke i täflan med desse sistnämnde stora kostsamma, men - hvarföre icke en liten början dertill! Denna början må blifva huru blygsam som helst, - blott vi hafva börjat - vi lemna fortsättningen åt efterverlden.

Brahestad den 21 October 1862

C. Ehrström 